\title{
PENGEMBANGAN PERANGKAT PEMBELAJARAN FISIKA BERBASIS KOMBINASI MODEL PEMBELAJARAN LANGSUNG DAN MODEL PEMBELAJARAN KOOPERATIF YANG DI IMPLEMENTASIKAN MELALUI KEGIATAN EKSPERIMEN PADA MATERI KALOR UNTUK MELATIHKAN KETERAMPILAN PROSES SAINS
}

\author{
Theo Jhoni Hartanto 1 \\ Soegimin W.W $\mathbf{W}^{2}$ \\ Wasis $^{2}$ \\ ${ }^{1)}$ Mahasiswa Pascasarjana Prodi Pendidikan Sains Universitas Negeri Surabaya \\ ${ }^{2)}$ Dosen Pascasarjana Pascasarjana Prodi Pendidikan Sains Universitas Negeri Surabaya
}

\begin{abstract}
Abstrak: Tujuan penelitian ini adalah untuk menghasilkan perangkat pembelajaran fisika berbasis kombinasi model pembelajaran langsung dan model pembelajaran kooperatif pada materi kalor yang valid, praktis, dan efektif untuk melatih keterampilan pros es sains. Pengembangan perangkat dalam penelitian ini mengadaptasi model. Validitas perangkat menunjukkan bahwa perangkat pembelajaran yang dikembangkan dapat digunakan dalam pembelajaran. Kepraktisan perangkat ditinjau dari: (a) Keterlaksanaan RPP 1 dan keterlaksanaan RPP 2 memperoleh kategori baik; dan (b) Aktivitas siswa yang dominan pada pertemuan pertama adalah memperhatikan penjelasan guru dan aktivitas yang dominan pada pertemuan kedua adalah mengerjakan LKS. Keefektifan perangkat ditinjau dari: (a) Ketuntasan hasil belajar kognitif produk sebesar 87,5\% di kelas VII-A dan 86,36\% di kelas VII-B; (b) Keterampilan proses sains melalui tes kinerja menghasilkan ketuntasan sebesar 75,00\% di kelas VII-A dan 86,36\% di kelas VII-B; dan (c) Respon siswa pada umumnya sangat positif terhadap perangkat dan kegiatan pembelajaran. Berdasarkan temuan-temuan hasil penelitian, dapat disimpulkan bahwa perangkat pembelajaran berbasis model pembelajaran langsung dan model pembelajaran kooperatif melalui kegiatan eksperimen yang dikembangkan valid, praktis, dan efektif untuk digunakan dalam kegiatan pembelajaran fisika pada materi kalor.
\end{abstract}

Kata-kata kunci: model pembelajaran langsung, model pembelajaran kooperatif, eksperimen, keterampilan proses sains, kalor

\section{PENDAHULUAN}

Tantangan bagi pengajar fisika adalah bagaimana merancang pembelajaran yang memberikan kemudahan dan kelancaran bagi siswanya dalam belajar fisika di sekolah. Sebagian besar siswa di sekolah menganggap mata pelajaran fisika merupakan salah satu mata pelajaran yang sukar untuk dipahami sehingga seringkali hasil belajar siswa tidak sesuai dengan apa yang diharapkan. Padahal terdapat banyak konsep menarik dalam fisika yang dapat dipelajari dengan pengalaman langsung di kelas. Pelajaran fisika dianggap sebagai pelajaran yang memaksa mereka menghafal, mengingat, dan mengulang rumus. Hammer1 dalam penelitiannya menemukan bahwa beberapa siswa merasakan bahwa belajar fisika adalah seperti belajar mengingat rumus- rumus, memecahkan masalah-masalah matematika, dan sebagian siswa meyakini bahwa fisika tidak berhubungan dengan dunia nyata. Benckert dan Pettersson2 menemukan bahwa banyak siswa yang belajar fisika tidak menemukan kemenarikan dari fisika dan banyak diantara mereka melewati pelajaran fisika tanpa memiliki pemahaman konseptual yang baik mengenai fisika itu sendiri. Tantangan ini harus dipecahkan oleh guru melalui proses pembelajaran yang dilaksanakannya di kelas.

Proses pembelajaran yang dilakukan di dalam kelas menjadi salah satu faktor utama yang menyebabkan kurang memuaskannya hasil belajar siswa. Sanjaya3 menyatakan bahwa salah satu masalah yang dihadapi dunia pendidikan di Indonesia adalah masalah lemahnya proses pembelajaran. Berdasarkan hasil wawancara dengan guru mata pelajaran IPA fisika kelas VII di SMPN 8 Palangka Raya, diperoleh keterangan bahwa dalam kegiatan pembelajaran guru lebih sering menggunakan metode ceramah tanpa kegiatan praktikum ataupun demonstrasi dalam membahas materi-materi fisika. Siswa belum pernah di bawa untuk melakukan kegiatan eksperimen dan belum pernah diajarkan mengenai keterampilan proses sains. Pada kegiatan pembelajaran, siswa biasanya diminta merangkum materi pelajaran dan mengerjakan latihan yang ada pada buku.

Berdasarkan hasil observasi peneliti juga diperoleh keterangan hasil belajar IPA untuk dua tahun ajaran terakhir masih belum optimal. Nilai rata-rata mata pelajaran IPA dua tahun pelajaran terakhir masih rendah, yaitu masih di bawah 60. Nilai rata-rata khusus untuk materi kalor di kelas VII-A dan kelas VII-B pada tahun pelajaran 2010- 
2011 masing-masing sebesar 59 dan 50. Nilai rata-rata untuk materi kalor di kelas VII-A dan kelas Vn-B pada tahun pelajaran 2011-2012 masing- masing sebesar 67,4 dan 52,1. Berdasarkan hasil wawancara dengan guru juga diperoleh keterangan bahwa penilaian untuk keterampilan proses sains siswa masih belum pernah dilakukan di kelas VII-A maupun kelas VTI-B. Hasil seperti ini mungkin saja diakibatkan metode ceramah yang digunakan guru selama proses pembelajaran sehingga kelas menjadi monoton. Inilah yang menjadikan materi yang ingin disampaikan tidak mengenai sasaran sehingga tidaklah mengherankan hasil belajar siswa jauh dari apa yang diharapkan. Pelajaran fisika diarahkan untuk "mencari tahu" tentang alam secara sistematis yaitu dengan "berbuat" karena sains bukan hanya penguasaan kumpulan pengetahuan.

Kegiatan "mencari tahu" dan "berbuat" dalam pembelajaran fisika memberikan pengertian bahwa siswa harus banyak dihadapkan kepada tindakan melakukan kegiatan-kegiatan eksperimen daripada hanya mendengar penjelasan guru atau membaca buku atau hanya terpaku kepada rumus-rumus yang bisa membuat siswa merasa bosan. Wellington4 menemukan bahwa melalui kegiatan eksperimen, pengetahuan dan pemahaman siswa terhadap sains cenderung meningkat. Siswa dapat melakukan kegiatan eksperimen untuk membuktikan atau menemukan konsep-konsep fisika yang sedang mereka pelajari.

Kalor merupakan salah satu konsep dalam kajian ilmu fisika yang selalu ditemui dan dialami sendiri oleh siswa dalam kehidupannya sehari-hari. Beberapa contoh peristiwa yang berkaitan dengan konsep kalor antara lain air dingin yang dipanaskan di dalam panci lama- kelamaan akan mendidih, segelas air dingin yang dicampur dengan segelas air panas akan menghasilkan air yang hangat, atau minyak goreng akan lebih cepat panas dibandingkan dengan air. Peristiwa-peristiwa dalam kehidupan sehari-hari tersebut merupakan beberapa contoh peristiwa yang berkaitan dengan kajian materi kalor yang selalu ditemui dan dialami oleh siswa dalam kehidupannya. Oleh karena itu, untuk mempelajari materi kalor adalah lebih baik jika siswa dibawa untuk "mencari tahu" dan "berbuat" secara langsung dengan peristiwa yang berkaitan dengan kalor itu sendiri. Inilah yang menjadi alasan mengapa metode eksperimen sangat cocok digunakan untuk mempelajari dan mendalami materi kalor. Dale5 menyatakan bahwa manusia belajar berdasarkan kerucut pengalamannya, yaitu 10\% dari apa yang di baca, 20\% dari apa yang di dengar, 30\% dari apa yang di lihat, 50\% dari apa yang di lihat dan di dengar, $70 \%$ dari apa yang dikatakan, dan 90\% dari apa yang dikatakan dan dilakukan sendiri.

Suparno6 menyatakan bahwa pembelajaran dengan metode eksperimen membuat siswa dapat melatih keterampilan-keterampilan yang berkaitan dengan mengamati, mengukur, mengumpulkan data, menganalisis data, dan menyimpulkan. Artinya, siswa dapat melatih keterampilan prosesnya melalui kegiatan eksperimen. Kegiatan pembelajaran seperti ini sejalan dengan pendekatan konstruktivisme. Pendekatan konstruktivisme merupakan pendekatan pembelajaran yang menekankan pada proses membangun atau menyusun pengetahuan baru berdasarkan pengalaman3. Pembelajaran dengan menggunakan pendekatan konstruktivisme pada dasarnya mendorong agar siswa dapat membangun pengetahuannya melalui proses pengamatan dan pengalaman, serta dapat mendorong siswa untuk mampu mengkonstruksi pengetahuan melalui pengalaman nyata.

Pendekatan kontruktivisme dalam pembelajaran di kelas salah satunya melalui model pembelajaran kooperatif. Slavin7 menyatakan bahwa dalam pembelajaran kooperatif, siswa bekerja sama dalam kelompok-kelompok belajar untuk saling membantu satu sama lain. Melalui pembelajaran ini, siswa diharapkan akan lebih mudah menemukan dan memahami konsep-konsep. Dalam konteks pembelajaran fisika, model pembelajaran kooperatif ini melibatkan kelompok- kelompok belajar untuk melakukan kegiatan eksperimen dalam mempelajari konsep-konsep fisika. Dalam aktivitas kelompok ini, siswa akan saling bahu-membahu untuk menyelesaikan persoalan yang diajukan guru melalui keterampilanketerampilan proses, misalnya menyusun hipotesis, menentukan variabel, mengumpulkan data sesuai prosedur, menganalisis data, dan menarik kesimpulan. Dengan demikian, siswa akan cenderung lebih aktif dalam kegiatan pembelajaran.

Namun, pelaksanaan dengan pembelajaran kooperatif masih terdapat kelemahan-kelemahan. Salah satu faktornya adalah guru dan siswa masih belum terbiasa dalam melaksanakan pembelajaran dengan pendekatan konstruktivis. Hal ini diakui oleh guru di SMPN 8 Palangka Raya. Guru-guru beranggapan bahwa pembelajaran kooperatif akan membuat kelas menjadi gaduh. Kegaduhan ini disebabkan siswa yang terbiasa pasif akan merasa bingung dan tidak tahu bagaimana bekerja sama menyelesaikan tugas atau melakukan kegiatan percobaan yang diberikan. Kebingungan ini juga mungkin disebabkan karena guru masih belum pernah melatihkan keterampilan proses sains kepada siswanya. Padahal di dalam pendekatan konstruktivis diharapkan bahwa pembelajaran pembelajaran fisika tidak hanya ditujukan pada penguasaan konsep-konsep tetapi juga mengembangkan kemampuan berinkuiri melalui penggunaan metode ilmiah dan mengembangkan sikap ilmiah. Oleh karena itu, menurut pemikiran peneliti, bagi 
yang ingin menggunakan pendekatan konstruktivisme dalam pembelajaran dapat dilakukan dengan perlahanlahan. Dengan demikian, diperiukan suatu cara agar pembelajaran dapat berjalan sesuai dengan yang diharapkan, salah satunya adalah dengan mengkombinasikan pembelajaran kooperatif dengan model pembelajaran langsung dalam mempelajari suatu materi. Model pembelajaran langsung adalah sebuah model yang berpusat pada guru8. Model pembelajaran langsung menghendaki guru memberikan informasi, mendemonstrasikan keterampilan yang sedang diajarkan, dan kemudian menyediakan waktu bagi siswa untuk latihan keterampilan tersebut dan menerima umpan balik tentang apa yang mereka lakukan9. Pembelajaran langsung dirancang untuk meningkatkan penguasaan keterampilan dan pengetahuan yang dapat diajarkan langkah demi langkah.

Dalam mengkombinasikan dua model ini akan didahului dengan pemodelan (model pembelajaran langsung) kemudian diikuti oleh model pembelajaran kooperatif. Veemnan, Denessen, van den Oord, dan Naafs10 mengemukakan bahwa menghilangkan pembelajaran langsung secara mutlak adalah sangat tidak mungkin, namun model ini akan memiliki kekuatan sebagai alat pembelajaran jika dikombinasikan dengan pandangan konstruktivisme. Beberapa hasil penelitian menyimpulkan bahwa model pembelajaran langsung dapat meningkatkan hasil belajar siswa dan sangat efektif dalam mengajarkan keterampilan siswa. Bahkan, Klahr dan Nigam11 melalui penelitiannya menemukan bahwa melalui pembelajaran langsung siswa dapat belajar lebih banyak memahami tentang fenomena-fenomena ilmiah (scientific phenomena) dan prosedurnya.

Melalui model kombinasi ini guru akan memodelkan terlebih dahulu yang berhubungan dengan apa yang akan dilakukan oleh siswa sebelum bekerja dalam kelompoknya masing-masing melalui kegiatan eksperimen. Dengan memodelkan tata cara melakukan kegiatan eksperimen terlebih dahulu diharapkan siswa tidak mengalami kebingungan dalam melaksanakan kegiatan eksperimen itu dalam kelompoknya sehingga kegiatan pembelajaran diharapkan berlangsung dengan baik dan tujuan yang diharapkan dapat tercapai. Kombinasi ini diharapkan dapat menjadi penghubung antara pandangan konstruktivisme yang mendasari pembelajaran kooperatif dan pandangan behavioristik yang mendasari pembelajaran langsung.

Berdasarkan uraian di atas, peneliti ingin mengkombinasikan model pembelajaran langsung (Direct Instruction) dan model pembelajaran kooperatif dengan berbasis pada kegiatan eksperimen serta menuangkannya dalam sebuah perangkat pembelajaran untuk membantu siswa memahami konsep yang diajarkan dan membuat pembelajaran yang melibatkan siswa sehingga dapat memperoleh hasil belajar yang baik. Tujuan penelitian ini adalah untuk menghasilkan perangkat pembelajaran fisika berbasis kombinasi model pembelajaran langsung dan model pembelajaran kooperatif yang valid, praktis, dan efektif untuk melatih keterampilan proses sains.

\section{METODE PENELITIAN}

Penelitian ini merupakan penelitian pengembangan, yaitu penelitian yang dimaksudkan untuk menghasilkan suatu produk dan menguji keefektifan produk tersebut 12 . Produk dalam penelitian ini berupa perangkat pembelajaran berbasis kombinasi model pembelajaran langsung (direct instruction) dan model kooperatif berbasis eksperimen pada materi kalor. Perangkat pembelajaran yang dikembangkan terdiri dari Rencana Pelaksanaan Pembelajaran (RPP), Lembar Kegiatan Siswa (LKS), Buku Ajar Siswa, dan Tes Hasil Belajar. Penelitian dilaksanakan di SMP Negeri 8 Palangka Raya, Kalimantan Tengah. Subyek penelitian ini adalah perangkat pembelajaran yang meliputi RPP, LKS, buku siswa, dan tes hasil belajar yang dikembangkan oleh peneliti. Perangkat pembelajaran ini diujicobakan di kelas Vn SMP Negeri 8 Palangka Raya, Kalimantan Tengah.

Pengembangan perangkat pembelajaran dalam penelitian ini mengadaptasi Model 4D (four D Models) yang disarankan oleh Thiagarajan, Semmel, dan Semmel. Model 4D terdiri dari empat tahap, yaitu tahap pendefinisian (define), tahap perancangan (design), tahap pengembangan (develop), dan tahap penyebaran (disseminate). Tahapan keempat belum dilakukan karena hasil pengembangan hanya diterapkan di satu sekolah.

\section{HASIL DAN PEMBAHASAN}

\section{A. Hasil Penelitian}

1. Validitas Perangkat

Setelah divalidasi oleh pakar dilakukan perbaikan sesuai saran dan masukan, maka diperoleh perangkat pembelajaran (draf 2) yang dapat digunakan untuk melakukan ujicoba II. Secara singkat mengenai validitas perangkat pembelajaran dapat dilihat pada Tabel 1

Tabel 1 Validitas Perangkat

\begin{tabular}{|l|l|l|}
\hline No & Perangkat Pembelajaran & Kriteria \\
\hline 1. & RPP & Valid \\
\hline 2. & LKS & Valid \\
\hline 3. & Buku siswa & Valid \\
\hline 4. & Tes Kognitif Produk & Valid \\
\hline 5. & Tes Kinerja & Valid \\
\hline
\end{tabular}


2. Kepraktisan Perangkat Pembelajaran

a. Keterlaksanaan RPP

Rata-rata kemampuan guru dalam melaksanakan kegiatan pendahuluan, kegiatan inti, dan kegiatan penutup yang tertuang pada RPP 1 memperoleh kategori baik. Secara umum, keterlaksanaan RPP 1, baik di kelas VII-A maupun VII-B, berkategori baik. Guru sudah bisa melaksanakan pembelajaran seperti langkah-langkah yang ada pada RPP 1 yang telah dikembangkan. Selain itu, guru mampu mengelola waktu dengan cukup baik.

Kemampuan guru dalam melaksanakan kegiatan pendahuluan, kegiatan inti, dan kegiatan penutup memperoleh kategori baik. Secara umum, keterlaksanaan RPP 2 pada kelas VII-A dan kelas VII-B adalah berkategori baik. Guru sudah bisa melaksanakan pembelajaran seperti langkah-langkah yang ada pada RPP 2 yang telah dikembangkan. Selain itu, guru mampu mengelola waktu dengan cukup baik.

b. Aktivitas Siswa

Hasil pengamatan aktivitas siswa pada pertemuan pertama dapat dilihat pada Gambar 1.

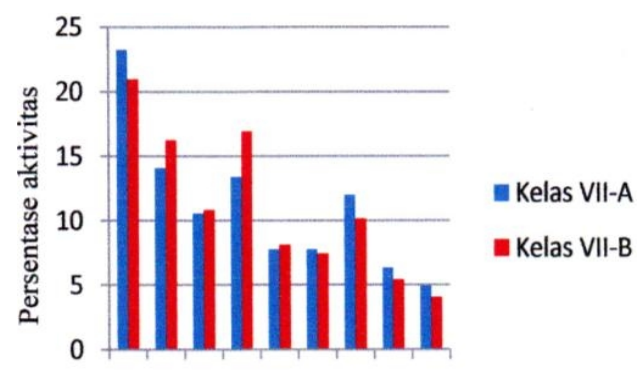

$\begin{array}{lllllllll}1 & 2 & 3 & 4 & 5 & 6 & 7 & 8 & 9\end{array}$

Aktivitas siswa pada pertemuan 1

1. Memperhatikan penjelasan guru

2. Memperhatikan demonstrasi oleh guru

3. Membaca (buku siswa dan LKS)

4. Melakukan kegiatan terbimbing pada LKS

5. Melakukan kegiatan latihan lanjutan

6. Bertanya kepada guru

7. Melakukan kegiatan diskusi

8. Menyampaikan hasil kegiatan pada LKS

9. Melakukan aktivitas yang tidak relevan

Gambar 1. Diagram aktivitas pertemuan 1 siswa kelas VII-A dan kelas VII-B

Hasil pengamatan aktivitas siswa pada pertemuan pertama dapat dilihat pada Gambar 2.

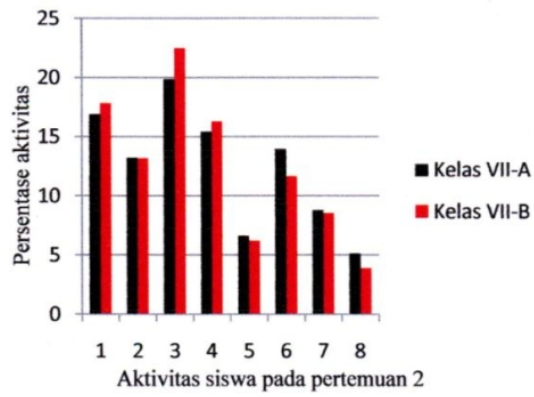

Aktivitas siswa pada pertemuan 2:

1. Memperhatikan penjelasan guru

2. Membaca (buku siswa dan LKS)

3. Mengerjakan LKS

4. Melakukan diskusi Menyajikan/mempresentasikan hasil percobaan kelompok

5. Bertanya kepada guru

6. Menyampaikan pendapat

7. Melakukan aktivitas yang tidak relevan

Gambar 2. Diagram aktivitas pertemuan 2 siswa kelas VII-A dan kelas VII-B

\section{Kefektifan Perangkat Pembelajaran}

A. Ketuntasan Hasil Belajar Kognitif Produk

Rata-rata hasil belajar di kelas VII-A dan VII-B meningkat setelah dilakukan kegiatan pembelajaran dengan mengombinasikan model pembelajaran langsung dan model pembelajaran kooperatif. Rata-rata nilai siswa kelas VII-A meningkat dari 25,13 menjadi 74,63 dan di kelas VII-B meningkat dari 27,18 menjadi 75,23 . Sebelum perlakuan semua siswa kelas VII-A dan VII-B tidak dapat mencapai kriteria ketuntasan minimal (KKM), setelah perlakuan persentase siswa yang dapat mencapai KKM di kelas VII-A dan VII-B masing-masing sebesar $87,5 \%$ dan $86,36 \%$.

\section{B. Keterampilan Proses Sains}

Siswa diminta untuk melakukan tes kinerja untuk melihat keterampilan proses sains yang dimiliki siswa. Keterampilan proses yang diamati pada saat siswa mengerjakan tes meliputi merumuskan hipotesis, mengidentifikasi variabel, melakukan eksperimen, menganalisis data, dan menyimpulkan hasil eksperimen. Selain itu diamati juga ketepatan waktu yang digunakan siswa untuk menyelesaikan tes. Hasil analisis tes disajikan pada tabel sebagai berikut.

Tabel 2 Hasil Tes Kinerja

\begin{tabular}{|l|l|l|}
\hline No. & Kelas & Ketuntasan \\
\hline 1. & VTI-A & $75 \%$ tuntas \\
\hline 2. & VII-B & $86,36 \%$ tuntas \\
\hline
\end{tabular}

\section{Respon Siswa}

Siswa memberikan respon yang positif terhadap kegiatan pembelajaran dengan menggunakan model pembelajaran langsung dan model pembelajaran kooperatif. Siswa memberikan respon positif terhadap buku yang disusun oleh peneliti $(55,17 \%$ siswa memilih sangat baik, $37,72 \%$ siswa memilih baik, dan $7,16 \%$ siswa memilih cukup baik). Siswa juga memberikan respon positif terhadap LKS yang disusun oleh peneliti (57,2\% siswa memilih sangat baik, 39,6\% siswa memilih baik, dan 3,2\% siswa memilih cukup baik). Berdasarkan hasil analisis respon juga diperoleh Sebanyak 59\% siswa menganggap cara guru mengajar selama kegiatan pembelajaran adalah sangat baik, 34,75\% menganggap baik, dan $6,25 \%$ 
menganggap cukup baik. Sedangkan untuk perangkat tes (tertulis dan kinerja), sebanyak 10,87\% siswa menganggap sangat mudah, 57,61\% menganggap mudah, 30,43\% menganggap cukup mudah, dan 1,09\% menganggap tes yang diberikan masih sukar untuk mereka kerjakan.

Siswa menilai kegiatan eksperimen dapat membuat mereka lebih memahami materi yang mereka pelajari. Seluruh siswa kelas VII-A dan kelas VII-B menyatakan bahwa kegiatan eksperimen (menentukan hipotesis, variabel, mengumpulkan data, menganalisis data, dan membuat kesimpulan) adalah sesuatu yang baru bagi mereka. Selain tu, siswa menyenangi suasana selama kegiatan pembelajaran berlangsung.

\section{B. Diskusi}

\section{Keterlaksanaan RPP}

Berdasarkan pada hasil pengamatan, guru sudah melaksanakan langkah-langkah utama dalam model pembelajaran langsung, yaitu fase persiapan dan motivasi yang kemudian diikuti oleh presentasi materi pelajaran dan demonstrasi keterampilan untuk melakukan kegiatan eksperimen, membimbing siswa melakukan kegiatan eksperimen dan memberikan umpan balik, serta memberikan kesempatan kepada siswa untuk melakukan kegiatan lanjutan. Guru memang tampak terlihat dominan karena model pembelajaran langsung yang diterapkan berpusat pada guru. Model pembelajaran langsung berorientasi pada arahan dan kontrol guru13. Namun demikian, bukan berarti siswa hanya menjadi pendengar. Siswa tetap terlibat dalam kegiatan pembelajaran yaitu melakukan kegiatan eksperimen dalam kelompok kecil pada tahap kegiatan terbimbing dan kegiatan lanjutan.

Walaupun secara keseluruhan keterlaksanaan RPP 1 di kelas VII-A dan kelas VII-B sudah baik, namun masih terdapat kekurangan. Kekurangan ini terletak pada pengelolaan waktu pembelajaran. Skor rata-rata dari pengamat berkategori cukup baik. Artinya, kemampuan guru dalam menggunakan waktu yang disediakan masih belum optimal. Waktu banyak tersita pada fase presentasi dan mendemonstrasikan, memberikan latihan terbimbing, dan memberikan latihan lanjutan. Hal ini disebabkan oleh dua hal, yaitu siswa merasa baru dengan kegiatan eksperimen dan materi kalor merupakan materi yang baru bagi siswa. Kedua hal ini membuat guru mendemonstrasikan tata cara melakukan eksperimen dan menyampaikan penjelasan mengenai materi terutama berkaitan dengan definisi kalor secara bertahap sehingga memerlukan waktu yang cukup lama. Slavin7 menyatakan bahwa jika guru memperkenalkan keterampilan atau konsep baru kepada siswa, mungkin dibutuhkan pembahasan yang lebih panjang. Eggen dan Kauchak13 menyatakan bahwa fase kedua dari pembelajaran langsung ini merupakan fase yang paling sulit bagi guru karena guru harus memberikan penjelasan agar siswa memahami informasi dan keterampilan yang disampaikan.

Tahap berikutnya, guru memberikan kesempatan kepada siswa untuk melakukan kegiatan terbimbing. Pada Tahap ini, guru masih membimbing kelompok-kelompok dalam melakukan kegiatan eksperimen. Joyce dan Weill13 menyatakan bahwa pada tahap ini peran guru mengontrol kerja siswa dan memberikan respon yang korektif. Pada tahap terakhir siswa melakukan latihan lanjutan. Pada tahap ini, peran guru sudah berkurang, namun masih ada beberapa kelompok siswa yang harus dibimbing menyelesaikan LKS. Oleh karena itu, waktu dalam kegiatan pembelajaran banyak digunakan pada tahap- tahap ini.

\section{Aktivitas Siswa}

Gambar 1 memperlihatkan diagram yang menggambarkan aktivitas siswa yang belajar dalam setting model pembelajaran langsung. Frekuensi aktivitas yang dominan merupakan ciri khas atau karakteristik dari model pembelajaran langsung. Joyce dan Weil13 menyatakan bahwa model pembelajaran langsung terdiri dari penjelasan guru mengenai konsep atau keterampilan serta memberikan peragaan, dilanjutkan dengan melakukan praktik di bawah bimbingan guru, dan mendorong mereka meneruskan ke praktik mandiri (latihan lanjutan). Frekuensi aktivitas yang paling dominan pada pertemuan pertama ini mencerminkan bahwa pembelajaran masih didominasi guru, dimana siswa cenderung dominan mendengarkan penjelasan. Suprijono15 menyatakan bahwa model pembelajaran langsung mengacu pada gaya mengajar dimana guru terlibat aktif dalam mengusung materi pelajaran kepada peserta didik dan mengajarkan secara langsung kepada seluruh kelas. Berdasarkan pengamatan yang dilakukan sepanjang kegiatan pembelajaran pada pertemuan pertama ini, guru dominan karena siswa masih belum terbiasa melakukan kegiatan eksperimen dan materi kalor merupakan materi yang baru dipelajari oleh siswa. Hal ini mengharuskan guru untuk memberikan informasi tentang materi kalor dan mendemonstrasikan keterampilan melakukan kegiatan eksperimen serta membimbing siswa melakukan kegiatan di LKS.

Berdasarkan pada Gambar 2 diperlihatkan bahwa pada pertemuan kedua ini, siswa terlihat lebih aktif dalam kegiatan pembelajaran. Siswa terlibat dalam mengerjakan LKS dalam kelompok untuk melakukan pengamatan/ melakukan eksperimen. Siswa melakukan kegiatan diskusi untuk menyelesaikan dan membahas hasil kerja kelompoknya. Nur16 menyatakan bahwa model pembelajaran kooperatif mengacu pada pembelajaran dimana siswa bekerjasama dalam kelompok kecil dan 
saling membantu dalam belajar. Tujuan yang hendak dicapai tidak hanya kemampuan akademik dalam pengertian penguasaan materi pelajaran, tetapi juga adanya unsur kerja sama untuk penguasaan materi tersebut.

Gambar 2 juga menunjukkan bahwa guru masih tetap terlibat selama kegiatan pembelajaran. Hal ini terlihat dari persentase sebesar 16,91\% (di kelas VII-A) dan $17,83 \%$ (di kelas VII-B), siswa beraktivitas mendengarkan penjelasan guru. Ini disebabkan masih ada kelompok yang kesulitan dan kurang percaya diri dalam menyelesaikan kegiatan pada LKS, sehingga guru harus membantu menanganinya. Guru kembali harus membimbing siswa untuk menentukan hipotesis dan menentukan variabel, dan menyimpulkan data serta mengingatkan tata cara melakukan eksperimen. Selain itu, guru memimpin kegiatan diskusi juga untuk menjelaskan konsep kalor dan pengaruhnya terhadap perubahan wujud zat. Guru memberikan penekanan dan koreksi terhadap hasil kerja siswa dan konsep yang mereka pelajari. Kegiatan pembelajaran pada pertemuan kedua ini jelas masih memerlukan pembimbingan dari guru karena bagaimana pun kegiatan eksperimen yang diterapkan ini masih baru bagi siswa sehinga masih banyak memerlukan pembimbingan.

\section{Ketuntasan Kognitif Produk}

Ketuntasan hasil belajar kognitif siswa memperlihatkan bahwa pada kelas VII-A mengalami peningkatan ketuntasan individu dari $0 \%$ menjadi $87,5 \%$ dengan nilai rata-rata meningkat dari 25,13 menjadi 74,63. Sedangkan, kelas VII-B mengalami peningkatan ketuntasan individu dari $0 \%$ menjadi $86,36 \%$ dengan nilai rata-rata juga meningkat dari 27,18 menjadi 75,23 . Hasil ini membuktikan bahwa kegiatan pembelajaran berbasis kombinasi model pembelajaran langsung dan model pembeJajaran kooperatif dengan bantuan kegiatan eksperimen dapat membantu siswa mempelajari konsep kalor.

Namun demikian, setelah proses pembelajaran, masih terdapat enam siswa yang belum mampu mencapai KKM. Rincian siswa-siswa tersebut adalah tiga siswa di kelas VII-A dan tiga siswa di kelas VII-B. Peneliti menganalisis hasil tes dari siswa-siswakelas VII-A dan kelas VII-B yang tidak tuntas, baik pada tes kognitif produk maupun tes kinerja.

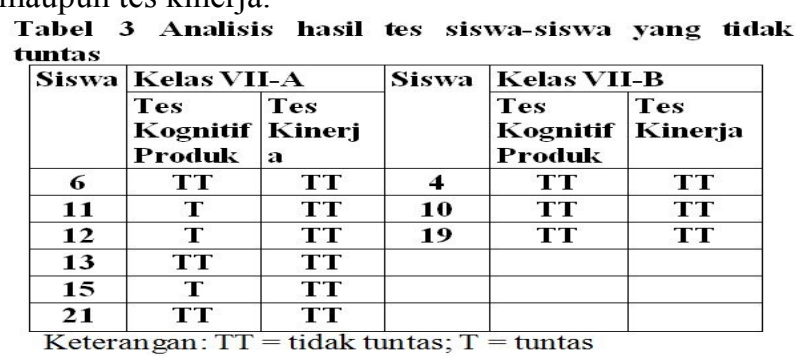

Pengembangan Perangkat Pembelajaran Fisika Berbasis Kombinasi Model Pembelajaran Langsung Dan Model Pembelajaran Kooperatif Yang Di Implementasikan Melalui Kegiatan Eksperimen Pada Materi Kalor Untuk Melatihkan Keterampilan Proses Sains
Berdasarkan Tabel 3, terdapat siswa-siswa yang masih memiliki kesulitan dalam kegiatan pembelajaran materi kalor. Hal ini didasari hasil bahwa enam siswa (siswa nomor 6, 13,21 di kelas VII-A dan siswa nomor 4, 10, 19 di kelas VII-B) belum berhasil mencapai kriteria pada tes kognitif produk dan juga tes kinerja. Suwarto17 menyatakan bahwa kesulitan belajar pada siswa dapat dilihat dari beberapa gejala, salah satunya adalah siswa menunjukkan hasil belajar yang rendah. Siswa-siswa ini perlu diberikan perhatian lebih agar dapat memperbaiki dan meningkatkan hasil belajarnya.

Berdasarkan Tabel 3 juga diperlihatkan beberapa siswa tuntas dalam tes kognitif produk, namun tidak tuntas pada tes kinerja. Artinya, siswa-siswa ini lebih baik dalam mengerjakan tes tertulis dibandingkan dengan tes kinerja yang menuntut kemampuan mereka menggunakan keterampilan proses sains. Siswa masih belum terbiasa melakukan tes yang berbentuk kinerja yang melibatkan keterampilan proses didalamnya. Hal ini diperkuat dari hasil respon seluruh siswa kelas VII-A dan kelas VII-B menyatakan bahwa kegiatan eksperimen (menentukan hipotesis, variabel, mengumpulkan data, menganalisis data, dan membuat kesimpulan) adalah sesuatu yang baru bagi mereka. Sanjaya3 menyatakan bahwa siswa terbiasa hanya sebagai penerima materi pelajaran dari gurunya sehingga mereka akan sulit ketika dibawa untuk memecahkan suatu permasalahan yang menuntut kemampuan berpikir dan keterampilan mereka. Berdasarkan hasil tes kognitif produk, juga ditemuukan bahwa sebagian siswa di kelas VII-B juga masih banyak yang salah berkaitan dengan konsep kalor jenis zat. Beberapa siswa di kelas VII-B memilih pilihan jawaban yang menyatakan bahwa benda dengan kalor jenis yang lebih besar akan menyerap kalor lebih cepat jika dibandingkan dengan benda yang memiliki kalor jenis yang kecil. Artinya, menurut siswa, benda akan cepat panas jika kalor jenisnya besar, sebaliknya, jika kalor jenisnya kecil maka benda akan lambat panas. Hasil ini juga terulang lagi ketika siswa harus menganalisis data dari beberapa zat dengan kalor jenis tertentu. Beberapa siswa lebih memilih jawaban yang mengurutkan benda dengan kalor jenis terbesar yang lebih cepat panas ke benda dengan kalor jenis yang lebih kecil yang lebih lambat panas.

Hal ini merupakan kesalahan konsep pada siswa yang juga pernah ditemukan oleh van den Berg18. Menurut peneliti, kesalahan konsep ini muncul karena siswa masih belum cukup memahami konsep kalor jenis benda walaupun sudah melakukan kegiatan eksperimen dalam kegiatan pembelajarannya. Urbancic dan Glazar4 menemukan bahwa walaupun siswa terlihat mampu melakukan pengamatan dalam kegiatan eksperimen, 
dan bisa membuat kesimpulan yang tepat dari ekperimen tersebut, namun mereka tidak dapat menghubungkan kesimpulan yang mereka peroleh dengan konsep sains yang ada dibaliknya. Hal ini akan memungkinkan penguasaan siswa menjadi tidaklah lengkap. Ibrahim19 menyatakan bahwa salah satu penyebab salah konsep karena penguasaan siswa pada kosep tersebut masih belum lengkap.

\section{Keterampilan Proses Sains}

Selain diberikan tes kognitif produk, siswa juga diminta untuk melakukan tes kinerja yang berkaitan dengan materi kalor untuk melihat keterampilan proses sains. Topik tes ini adalah tentang titik didih dua jenis zat (air dan air garam). Adapun hasil dari tes kinerja secara keseluruhan seperti yang disajikan pada Tabel 4.13. Pada kelas VII-A dan kelas VH-B masing-masing terdapat 18 siswa dan 19 siswa telah mencapai KKM yang telah ditetapkan (sebesar lebih dari atau sama dengan 65). Artinya, pembelajaran pada materi kalor ini sudah bisa melatihkan keterampilan proses sains pada siswa.

Peneliti beranggapan bahwa hasil ini dicapai karena siswa terus dilatih selama dua pertemuan untuk melakukan kegiatan eksperimen. Pada pertemuan pertama, guru memodelkan terlebih dahulu bagaimana melakukan eksperimen dan menggunakan keterampilan ilmiah. Hal ini dilakukan agar siswa memiliki gambaran tentang apa yang akan dilakukannya. Suprijono14 menyatakan bahwa melalui pengamatan terhadap apa yang dilakukan guru (model) maka siswa dapat dapat meniru perilaku (langkah-langkah) yang dimodelkan atau terampil melakukan kegiatan seperti yang dimodelkan Kemudian, siswa melakukan eksperimen dengan bimbingan guru untuk merumuskan hipotesis, menentukan variabel, memilih dan merangkai alat percobaan, melakukan pengumpulan data (melakukan percobaan), mencatat data ke dalam tabel, dan menyimpulkan hasil percobaan. Walaupun siswa masih belum terbiasa dalam melakukan tes kinerja dengan melakukan eksperimen seperti hasil dalam angket respon dimana mereka merasa baru dalam melakukan eksperimen, termasuk dalam membuat hipotesis, mengidentifikasi variabel, mengumpulkan data, dan membuat kesimpulan, tapi mereka sudah mencoba dan antusias untuk mengerjakannya dengan baik.

Berdasarkan pada hasil tes kinerja yang dilakukan oleh siswa kelas VII-A dan siswa kelas VII-B, diperoleh siswa tuntas masing-masing sebesar $75 \%$ dan $83,36 \%$. Siswa-siswa yang tuntas ini sudah bisa melaksanakan kegiatan eksperimen dengan menggunakan keterampilan proses. Salah satu contoh jawaban siswa yang tuntas pada tes kinerja adalah sebagai berikut.

\section{Hipotesis:}

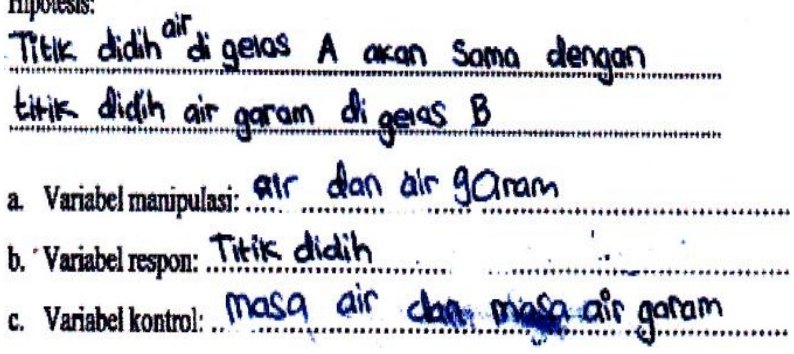

Tabel Pengamatan

\begin{tabular}{|c|c|c|}
\hline \multirow{2}{*}{ Waktu (menit) } & \multicolumn{2}{|c|}{ Suhu ${ }^{\circ}$ C } \\
\cline { 2 - 3 } & 50 gram air & 50 gram air garam \\
\hline 0 & 29 & 30 \\
\hline 1 & 34 & 34 \\
\hline 2 & 38 & 40 \\
\hline 3 & 44 & 44 \\
\hline 4 & 54 & 53 \\
\hline 5 & 61 & 60 \\
\hline 6 & 69 & 65 \\
\hline 7 & 75 & 44 \\
\hline 8 & 83 & 82 \\
\hline 9 & 85 & 84 \\
\hline 10 & 87 & 86 \\
\hline 11 & 8 & 87 \\
\hline 12 & 89 & 89 \\
\hline 13 & 89 & 89 \\
\hline 14 & 89 & 90 \\
\hline 15 & & 91 \\
\hline 16 & & 91 \\
\hline 17 & & \\
\hline 18 & & \\
\hline 19 & & \\
\hline 20 & & \\
\hline
\end{tabular}

\section{Berdasartan data hasil eksperimen, berapakah titik ditäh air?} Jawaterin. 89

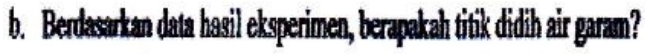

Jawabar: 9

c. Berdesatan hasil eksperimen, apatah titik didith air sama dengan titit didith air

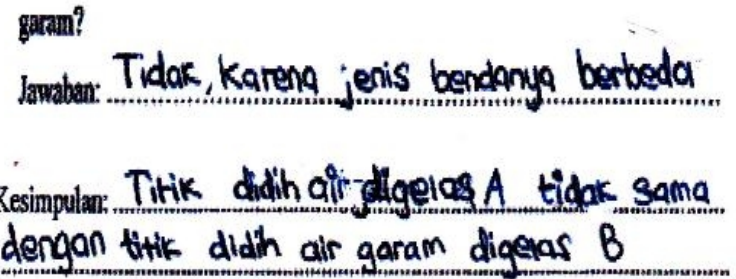

Jawaban di atas raerupakan salah satu contoh jawaban dari siswa yang tuntas dalam menyelesaikan tes kinerja. Berdasarkan jawaban yang disajikan, terlihat siswa sudah benar dalam merumuskan hipotesis, menuliskan variabel, menganalisa data, dan menuliskan kesimpulan berdasarkan data yang diperolehnya. Untuk merekam data hasil ekperimen dalam tabel, siswa ini juga sudah benar. Artinya, siswa ini sudah bisa menguasai keterampilan proses yang dilatihkan kepadanya selama kegiatan pembelajaran. 
Namun demikian, berdasarkan hasil pelaksanaan tes kinerja, juga diperoleh bahwa dari kelas VII-A dan VII-B masih terdapat sembilan siswa yang masih belum tuntas. Enam dari sembilan siswa yang belum tuntas ini juga tidak mencapai ketuntasan dalam tes kognitif produk dan tiga siswa lainnya hanya tuntas dalam tes kognitif produk (seperti disajikan pada Tabel 3).

Berdasarkan pada analisis jawaban siswa pada lembar tes kinerja, siswa yang belum mencapai kriteria ketuntasan ini masih kesulitan dalam merumuskan hipotesis, mengidentifikasi variabel percobaan, menganalisis data, dan membuat kesimpulan dengan benar. Hasil yang hampir sama seperti ini juga pernah ditemukan oleh Chabalengula, Mumba, dan Mbewe20 bahwa beberapa siswa mengalami kesulitan dalam menggunakan keterampilan proses terutama mengidentifikasi variabel dan menarik kesimpulan.

Keterampilan proses sains yang diteliti ini tentu saja berkaitan erat dengan kurikulum 2013. Kurikulum ini mengamanatkan esensi pendekatan ihniah dalam pembelajaran. Pendekatan ilmiah diyakini sebagai fondasi perkembangan dan pengembangan sikap, keterampilan, dan pengetahuan peserta didik. Metode ilmiah umumnya menempatkan fenomena unik dengan kajian spesifik dan detail untuk kemudian merumuskan simpulan umum. Untuk dapat disebut ilmiah, metode pencarian (method of inquiry) hams berbasis pada buktibukti dari objek yang dapat diobservasi, empiris, dan terukur dengan prinsip-prinsip penalaran yang spesifik. Oleh karena itu, metode ilmiah umumnya memuat serangkaian aktivitas pengumpulan data melalui observasi atau ekperimen, mengolah informasi atau data, menganalisis, kemudian memformulasi, dan menguji hipotesis. Rangkaian kegiatan inilah yang dilatihkan oleh peneliti kepada para siswa agar mereka terbiasa untuk bekerja secara ilmiah, khususnya dalam kegiatan pembelajaran IPA.

\section{Respon Siswa}

Secara keseluruhaii, siswa di kelas VII-A dan kelas VII-B memberikan respon yang positif terhadap perangkat (buku siswa dan LKS). Berdasarkan analisis hasil respon juga diketahui bahwa kegiatan pembelajaran membantu mereka lebih mudah dalam menentukan hipotesis, variabel, mengumpulkan data, menganalisis data, dan membuat kesimpulan. Ini didukung oleh respon positif mereka terhadap cara mengajar yang dilakukan oleh guru selama kegiatan pembelajaran. Selain itu, kegiatan eksperimen yang mereka lakukan (termasuk menentukan hipotesis, variabel, mengumpulkan data, menganalisis data, dan membuat kesimpulan) adalah sesuatu yang baru.
Hasil-hasil respon tersebut diperkuat oleh beberapa kesan siswa selama kegiatan pembelajaran. Beberapa kesan siswa disajikan sebagai berikut:

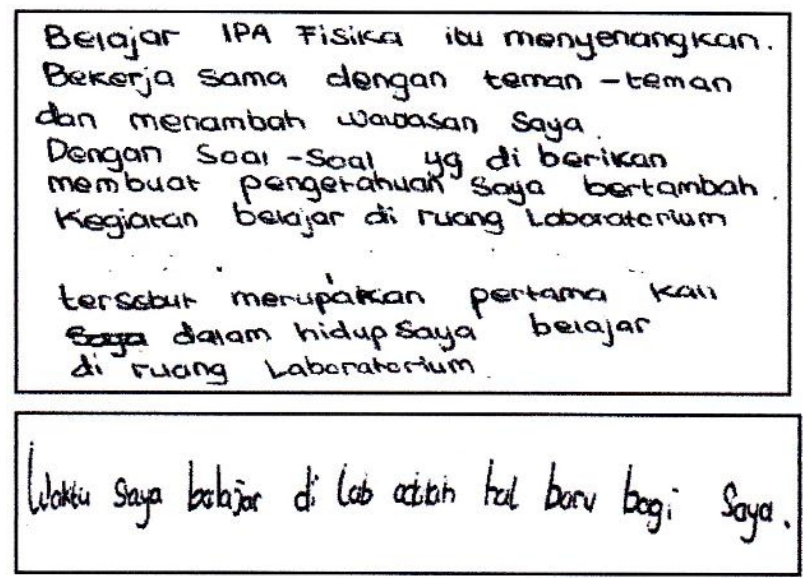

\section{SIMPULAN}

Berdasarkan hasil analisis, diskusi, dan pembahasan, maka dapat disimpulkan bahwa perangkat pembelajaran yang dikembangkan berbasis model pembelajaran langsung dan model pembelajaran kooperatif melalui kegiatan eksperimen, sudah valid, praktis, dan efektif untuk melatih keterampilan proses sains dalam kegiatan pembelajaran fisika.

\section{DAFTAR PUSTAKA}

Sahin, M. 2009. Exploring University Students' Expectations and Beliefs About Physics and Physics Learning in Problem Based Learning Context. Eurasia Journal of Mathematics, Science, Technology Education, 321-333.

Benckert dan Pettersson. 2008. Learning Physics in Small- Group Discussions - Three Examples. Eurasia Journal Of Mathematics, Science, and Technology Education, 121-134.

Sanjaya, Wina. 2011. Perencanaan dan Desain Sistem Pembelajaran. Jakarta: Kencana Prenada Media Group. Urbancic dan Glazar. (2012). Impact of Experiments on 13 years-old pupils' Understanding of Selected Science Concepts. Eurasia Journal of Mathematics, Science, and Technology Education, 207-218.

Komalasari, Kokom. 2011. Pembelajaran Kontekstual: Konsep dan Aplikasi. Bandung: PT Refika Aditama.

Suparno, Paul. 2007. Metodologi Pembelajaran Fisika:

Konstruktivistik dan Menyenangkan.Yogyakarto.: Universitas Sanata Dharma.

Slavin, R. (2011). Psikologi Pendidikan Teori dan Praktik Jilid Satu. Jakarta: PT Indeks.

Arends, R. I. 2008. Learning to Teach : Belajar untuk Mengajar Edisi Ketujuh Buku Satu. Yogyakarta: 
Pustaka Pelajar.

Nur, M. (2011). Model Pengajaran Langsung. Surabaya: Unesa: PSMS.

Veenman et al. (2003). The Influence of a Course on Direct and Activating Instruction upon Student Teachers' Classroom Practice. Journal of Experimental Education, 197-225.

Klahr dan Nigam. 2004. The Equivalence of Learning Paths in Early Science Instruction: Effect of Direct Instructon and Discovery Learning. Association for Psychological Science, 661-667.

Sugiyono. 2011. Metode Penelitian Pendidikan. Bandung: Alfabeta.

Joyce dan Weill. 2009. Models of Teaching: Modelmodel Pengajaran. Yogyakarta: Pustaka Pelajar.

Eggen dan Kauchak. 2012. Strategi dan Model Pembelajaran: Mengajarkan Konten dan Keterampilan Berpikir. Jakarta: PT Indeks.

Suprijono, A. (2012). Cooperative Learning: Teori dan Aplikasi PAIKEM. Yogyakarta: Pustaka Pelajar.

Nur, M. (2008). Pengajaran Berpusatpada Siswa dan Pendekatan Konstruktivis dalam Pengajaran edisi 5. Surabaya: Unesa: PSMS.

Suwarto. 2013. Pengembangan Tes Diagnostik dalam Pembelajaran. Yogyakarta: Pustaka Pelajar.

Van den Berg, Euwe. 1991. Miskonsepsi Fisika dan Remidiasi. Salatiga: Universitas Kristen Satya Wacana.

Ibrahim. Muslimin. 2012. Seri Pembelajaran Inovatif: Konsep, Miskonsepsi, dan Cora Pembelajarannya. Surabaya: Unesa Press.

Chabalengula, Mumba, dan Mbewe. 2012. How Pre-service Teachers' Understand and Perform Science Process Skills. Journal of Research in Science Teaching, 167176. 